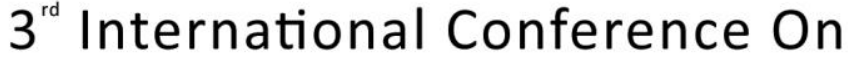 Advanced Research in EDUCATION \\ 11-14 March, $2021 \quad$ Oxford - United Kingdom
}

\section{Expat Student in The Mirror. The Power of Creative Narratives Through a School Blog and Online Magazines}

\author{
Agata Bogdańska \\ European School of Varese \\ Varese, Italy
}

\begin{abstract}
.
Building stories, anecdotes or our own opinions on various topics has been an important component in acquiring knowledge and skills in life for centuries. For expat teenagers, i.e. rootless students who have never lived in their country of birth or left it when children, such activity is of great importance nowadays. It explains who they are, helps them understand their own identity, strengths and weaknesses and at the same time they will feel better in a group of peers from other countries and cultures.

New digital tools such blogs, vlogs and school online magazines provide a wider audience but also require caution and responsibility for one's creativity, directly comparing their own achievements with the peers' ones. The new tools also have offered teenage students incredible opportunities to explore the psyche. The result of this internal analysis is a better contact with themselves and, consequently, with other members of the communities which students are part of.
\end{abstract}

Keywords: expats; narratives; blog; online; magazine; 


\section{$3^{\text {rd }}$ International Conference On Advanced Research in EDUCATION}

11-14 March, $2021 \quad$ Oxford - United Kingdom

\section{Introduction}

I like digging holes and hiding things inside them

When I grow old I hope I won't forget to find them

'Cause, I've got memories and travel like gypsies in the night.

I build a home and wait for someone to tear it down

Then pack it up in boxes, head for the next town running

'Cause, I've got memories and travel like gypsies in the night.

And a thousand times I've seen this road

A thousand times.

I've got no roots, but my home was never on the ground. (...)

Ask me where I come from, I'll say a different land.

- Alice Merton sings, and her extremely wise words could be indisputably and immediately recognized as the official song of many international schools around the world, including mine: European School in Varese in Lombardy (Italy). In fact, countless of our students do not live in the country where they were born, have the blood of several nations in their veins since they have grandparents or parents of different nationalities that often change their place of residency because of their job. Such a life is generally not good for teenagers, least of all easy and carefree.

It is worth briefly introducing the essence of the expat child syndrome or - in this case - the expat teenager syndrome. It is an issue related to the emotional stress of young people caused by going abroad and the problems with integration with their peers in a new place. The most common symptoms of expatriate child syndrome are changes in the behavior of our students visible to the naked eye, e.g. a tendency to isolation and introversion, a sense of loneliness and suffering, excessive aggression or apathy.

It would seem that due to Covid pandemic, the world has stopped for a long time nowadays, and difficulties in moving effectively blocked the parents' race for a better life (whatever better life means). But is it really so? However, observing the processes taking place in international schools in Lombardy, it turns out that students moving during the lockdown spells has not decreased. On the contrary, last year (2020) seems to have intensified the decisions of families to leave and move, for example, to another continent or to return to the country of one the parents. 


\section{$3^{\text {rd }}$ International Conference On Advanced Research in EDUCATION}

11-14 March, $2021 \quad$ Oxford - United Kingdom

In any case, it is also worth noting that switching from one extreme (constantly moving and changing places) to another (not being able to leave the house because of Covid) for teenagers is not a solution at all. It certainly will not bring long-term relief, it will not cure problems if they had any prior the lockdown, but on the contrary it will make them worse. Therefore, neither frequent moving nor being locked at home benefit young people who, after all, have no previous life experiences to assist them. Today's teens find themselves in the same position as adults in coping with a complicated pandemic situation. However, due to their age, they lack practical and basic model they can rely on to develop effective resilience.

How to live in a world where absolute uncertainty is not a flaw but a trait? To survive and thrive in such a world, you'll need extraordinary mental flexibility and powerful reserves of emotional balance. (...) Endurance cannot be learned by reading a book or listening to a lecture. (...) But if you want to keep some control over your own existence and the future of life (...) you need to know yourself. ${ }^{1}$

So how, faced with a reality where the last thing is to feel safe and to have clear perspective about the future, work effectively with rootless teenagers? How to ensure that, despite the complicated living conditions, students do not stop developing to speak and write better in their native language? How can we help them understand themselves and make their lives happier? It's quite a challenge, but maybe I've found a way to do it with creativity, introspection, and the help of Internet.

\section{Practical application of the theory of self-perception in creating student's blogs}

The theory of self-perception is an excellent framework that perfectly combines the three issues above, as well as more fully defining the purpose of the teacher's activities. This theory, which has been gaining popularity over the years, is about how we collect information about ourselves. How do we know who we are and how do we imagine it? The theory, created in 1972 by Daryl Bem, is based on the belief that in order to get to know yourself, one should observe one's own reactions in a given situation and draw conclusions, eg if, during a sad movie, tears pop into my eyes, it means that I was probably touched because I am a sensitive person. Another way to get to know yourself is the so-called "Social mirror", that is to compare yourself with other members of the community and draw conclusions about yourself on this basis.

The claim that self-knowledge in human life of all ages is necessary in order to feel good in one's own skin and get along with others is irrefutable. At a young age, creative writing (but also introducing yourself through recordings) is not just an addition to school duties, it can be a useful tool for recognizing students' strengths and weaknesses, better formulating their thoughts, and it can create a friendly, non-compulsory atmosphere without pressure.

${ }^{1}$ Y.N. Harari, 21 lekcji na XXI wiek (21 lessons for the 21st Century). Wydawnictwo Literackie Press. Warsaw, 2018, pp. 339. 


\section{$3^{\text {rd }}$ International Conference On Advanced Research in EDUCATION}

11-14 March, $2021 \quad$ Oxford - United Kingdom

Moreover, in the classroom, narratives serve as a powerful memory tool and a blueprint for behavior and self-identity. (...) A learner's self-narrative, either good or bad, becomes a blueprint for thoughts, feelings, and behaviors that turn into self-fulfilling prophecies. (...) Editing negative self-narratives can be a central component of transforming a challenged learner into a successful student. $^{2}$

For several years, my Polish students from the European School in Varese have been running the school blog "All roads lead to 66 bis". ${ }^{3}$ The name sounds puzzling, but its explanation is simple: there was a Polish-language room at this number. In the meantime, the school has introduced a new numbering of the classrooms, but the name of the blog, previously selected in the competition, has remained unchanged. Although we are unable to write continuously throughout the school year, we try to make sure that interesting texts for young people (written by them, of course) appear at least twice a year - high linguistic level in each semester.

We use the platform primarily to practice creative writing. After all, a blog is there to break away from gray, ordinary, and sometimes disappointing reality for a while, to imagine a different, perhaps more satisfying world, and why not dream it. So most of the lyrics are stories made up by students with their own logic. There are also essays - opinion-forming and very personal texts. On the blog we also publish reports of the internship, texts that refer to the classics of European literature, but also very spontaneously photos from of the trip or drawings. Here is an example of a very current and humorous version that refers to the book by the Polish writer Dorota Masłowska, which is also a recipe parody:

\section{How to culinary protect yourself from the virus Covid 19}

Upon awaking each morning we are bombarded with stressful news about the Coronavirus epidemic. (...) It doesn't matter where the epidemic broke out, but how to prevent it.

Here is a simple and effective recipe for biological and mental recovery during this pandemic outbreak:

Ingredients:

Car or train ticket to Macugnaga,

10 euros,

Warm winter clothes and mountain shoes

\footnotetext{
${ }^{2}$ L. Cozolino, The Social Neuroscience of Education. W.W. Norton \& Company Press. New York, London 2013, pp. 21.

${ }^{3}$ The full name of the Polish students' blog in Varese is: www.wszystkiedrogiprowadzado66bis.wordpress.com (access: 21.02.2021) where all the students' texts quoted below can be found.
} 


\section{$3^{\text {rd }}$ International Conference On Advanced Research in EDUCATION}

11-14 March, $2021 \quad$ Oxford - United Kingdom

To start with, you should climb to the top of Monte Rosa in the Alps, or at least hike one of the many mountain trails. While walking, it is worth breathing in the fresh mountain air, exposing yourself to the warm rays of the sun, listening to the silence interspersed with the noise of trees and admiring the breathtaking view of the almighty Alps. Then, tired but very happy, we go to the local pastry shop in the center of Macugnaga - Pasticceria Jager Bar, where hot chocolate and a huge selection of delicious cakes at affordable prices will compensate us for the lack of energy after a tiring but wonderful physical effort.

While sipping on delicious hot chocolate, it is also worth admiring the views and incredibly friendly atmosphere of the patisserie, where residents are happy to chat with tourists from all over the world (even from China!). There are no prejudices here and no one to blame for the current crisis. Everyone here feels the atmosphere of kindness and openness of the owners of the pastry shop and their guests. What's more, you can come here with your pet or carelessly stroke the dog of guests sitting at the next table.

This day can be repeated every day until the end of your stay in the mountains. (Nina)

Another recent project which I really like is called short story line. This is a continuation of the story started by the previous person. In our case, the topic was inspired by an eccentric interview and was called: "Library as an epidemic." I adore short story line, it is my favourite form of work with young people, because it is not only about creating a story, but also that the language and topic must match the previous one. It's also about preparing the end of the text so that, just like scrabble, it can be combined and have common points with the text of the next person writing. What's more, the continuation of the first part can branch in parallel almost without limits, which can be even more fun for students. Here is an example:

What are you doing ?! Kamila shouted confused.

In response, he took her other books and threw them out the window.

- How dare you?! - Kamila was still shouting shocked.

Then the man as if nothing happened, handed his newspaper. This time she understood everything she read. Still, she didn't care. Her attention was drawn to the date in the upper right corner: August 29, 2056. After a few minutes, however, she decided to focus on the content of the main page article...

"The Library epidemic is widely announced. Polish scientists officially warn that you can be addicted to books. Libraries are starting to be built on every street. People besiege them from all sides. They don't eat, don't drink, they read for days without reflection. "All this must end before it's too late. The only and last resort is Jonas Strik, "warns Dr. Marek Staniewski." (Nina) 


\section{$3^{\text {rd }}$ International Conference On Advanced Research in EDUCATION}

11-14 March, $2021 \quad$ Oxford - United Kingdom

The story continues:

Kamila took a deep breath. The events of the moment were beginning to reach her brain. She tried to calm down, but her pressure was still raging. She sat in the train compartment for a long moment, staring at the sunrise. It wasn't until after a few minutes that she began to feel the lack of books. She looked around the compartment, discreetly looked under the seats, opened the travel bag as if searching for a warmer sweater. From time to time, Kamila looked at the mysterious man, and the more time she wasted searching for a book, the stronger the anger she felt towards him, which anger eventually turned into hatred. (Igor)

It is also worth mentioning the oral statements on the blog - podcast and vlog. So far, Polish students have prepared podcasts in which they comment on topics that interest them (eg Silesian cuisine), as well as recordings (videos) in which they talk about their favorite books and inventions. By jointly analyzing the tasks during the lesson, the student can reflect on their strengths and weaknesses in public speeches evaluate their future chances in the public space.

What is the role of the teacher in this project? Is he or she just a humble technician willing to put students' texts online? Absolutely not! The teacher is rather a Steven Spielberg! I would compare his role to that of a director in a play - the viewer will not see him or her on stage, but at any moment he or she can feel his/her vigilant presence behind the curtain, because it is so. Teacher director who plans and directs students, releasing all layers of creativity in them. Students have a great freedom of choice, but the teacher decides the final form of the project.

Here are some practical information on the school blog:

\section{Tips \& Tricks}

1. Don't force the students to start a blog since it should not become an unpleasant duty.

2. Before starting the task, have parents' written permission to publish the students' surnames, their texts, photos, drawings and videos on Internet.

3. Create the blog rules together with your students.

4. Give them a lot of room to choose the themes they like - don't be too rigid about it.

5. If possible, make your own blog or vlog. So you can really understand how it works and what you can actually request from your students.

6. Don't criticize them too much, focus on the positive messages. Always give high grades for this type of work.

7. Always think of blogs / vlogs not as an end goal but only as the tool that can help to develop your students.

\section{Terms and Conditions}

1. Each of the Polish students of the High School of the European School in Varese has unlimited access to the blog and the email that was used to open the blog. 


\section{$3^{\text {rd }}$ International Conference On Advanced Research in EDUCATION}

11-14 March, $2021 \quad$ Oxford - United Kingdom

2. In our posts we use only a good-standard Polish language.

3. Each of us writes freely without anybody forcing us.

4. Every photo attached to the blog is preceded by a text.

5. In any way we do not interfere in the posts of other students.

6. We write so as not to offend any of our possible readers.

7. We only attached photos of ourselves and nobody else.

8. Each blogger has the right to post a friend's ("guest's") text, but this must be in Polish. In this case, however, this is a separate initiative and the publications of other people (i.e. "guests") is in no way connected with the European School in Varese.

9. Frequent, systematic posts at a high level of language and content will raise the assessment for the Polish language and on the contrary - the not so good ones will lower the grades.

10. All disputed issues related to the use of our blog and the materials posted on the blog are in charge of our Polish teacher Agata Bogdańska, who is also the administrator of the blog and the only person responsible for the blog content.

\section{Teenage narratives in the online magazine of Polish students of the Polish Consulate School in Milan}

You don't really need much to create an online newspaper: bit of enthusiasm and a regular computer. The magazine prepared by the students of the Polish Consulate School in Milan can be found on the School's website, it appears two or three times a year. The texts and the colourful pictures are funny, serious, surprising and undoubtedly extremely diverse. There are sports articles, recipes, poems and language games, drawings and photos, stories about animals, holidays, free time and school, presenting the world of teenagers and more serious texts, because they cover current issues, e.g. issues of cyber bullying, teenage rebellion, tolerance, racism, terrorism or Polish and Italian identity and history, as well as private matters as feelings:

Love can be painful. For example, it may happen that the person you fall in love with does not look at you. I also think that boy and girl can be friends. Why not? I know that sometimes friendship becomes love, but not always. Everyone should fall in love at least once. If you're in love, the world seems so cool ... (Gaia)

DISCRIMINATION AND RACISM are two things I hate, in my opinion they don't make sense, after all we are all the same, the only thing we differ is the colour of the skin and the country of origin. In my opinion, racists are above all people who have their own way of thinking and are not open to others. For years, Europeans thought they were better than others and used people from other continents as inferiors. But such things happened 200 years ago, a lot has changed since then.

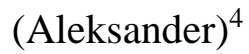

\footnotetext{
${ }^{4}$ The texts come from the site: https://mediolan.orpeg.pl/dwumiesiecznik-pl/ (access: 21.02.2021)
} 


\section{$3^{\text {rd }}$ International Conference On Advanced Research in EDUCATION}

11-14 March, $2021 \quad$ Oxford - United Kingdom

\section{International magazine of the European School's students in the context of Culturally Responsive Teaching}

Culturally Responsive Teaching is another theory that undoubtedly and significantly enriches the discourse on exploration of their own psyche by students of international schools today, improving life and wellbeing. This theory is based on teaching that takes into account the cultural identity of students, recognizes and supports multiculturalism, sensitizes them to the country of origin and respects the customs of all members of the group who learn together at school. It is the awareness that students bring their knowledge, experience and traditions of the country they come from into the classroom every day. It is worth sharing these experiences as they will also enrich other group members.

In the European School of Varese, and more specifically on the Internet, there is a place for this type of activity: a magazine where students of different nationalities tell stories, sharing their own experiences in English and Italian ${ }^{5}$ :

This year due to the covid-19 pandemic, many of us will not be travelling anywhere (at least not physically). Still, we can enjoy lots of things at home and traditions are things that can make our holiday seasons so special. And as we are lucky to be in a truly international school, with students from around 47 different countries, we asked students to share the special traditions in their home countries.

In Italy there are different traditions depending on the region. In southern Italy is Christmas less characteristic, mainly because of the warm temperatures. When I think about Christmas, I imagine street markets, Glühwein, cold, snow and of course decorations. The more north you are, the more you see those things. In Trentino Alto Adige for example there is a peaceful and wonderful Christmas atmosphere. (Elena)

Christmas time in Ireland is guaranteed to be something magical for anyone who experiences it. It has certainly always been this way for me. Being born abroad, and never having lived in the country where I claim to be from, our yearly trips home are always of great importance to me. (...) Christmas Day itself mainly revolves around food. At least in my family, it does. During the delightful task of seeing what Santa left you, people often enjoy a healthy breakfast of chocolate in many forms: chocolate coins, chocolate selection boxes, and Terry's chocolate orange, to name a few. But this is only pre-breakfast. Following this, in Northern Ireland, we eat plum duff, a sort of rich, crumbly Christmas cake full of dried fruit, fried in butter and served with salty bacon. Delicious(ly bad for you)! (Emily)

\footnotetext{
${ }^{5}$ The texts come from the site: https://esvnews19.wixsite.com/journal-club/post/christmas-traditions-around-the-world (access: 21.02.2021)
} 


\section{$3^{\text {rd }}$ International Conference On Advanced Research in EDUCATION}

11-14 March, $2021 \quad$ Oxford - United Kingdom

The period of the Christmas holidays in Ukraine is characterized by an abundance of traditional rituals, Christmas Carols, and historically rich Ukrainian folklore. It is celebrated 13 days after the 25th of December, on the 7th of January. (...) "Carol of the Bells" is an Ukrainian traditional Christmas Carol, which many people know. You probably do not know that it has originated in Ukraine, but you have heard the tune (like in the "Home Alone 1" movie). It was composed by the Ukrainian composer Mykola Leontovych, while an English text was created later by American (of Ukrainian descent) composer Peter J. Wilhousky, who wrote lyrics entirely unrelated to the original ones. The carol is based on a folk chant known in Ukrainian as "Shchedryk". (Alessandra)

\section{Summary}

Many researchers today believe that talking about students' narratives is outdated, that this topic is too trivial or too broad to be drawn to. However, Louis Cozolino cannot be in that group when he says:

Stories are transferred from brain to brain across the social synapse and serve to integrate the functioning of individuals within groups by teaching skills, transmitting values, and creating shared perspectives and goals. ${ }^{6}$

The statement that the possibility, ability, and willingness to tell stories at school undoubtedly integrates students (especially those without roots) can be taken for granted nowadays. But we must remember that our world is changing rapidly, and teenagers today offer us different stories than those told by teens several dozen or just a few years ago. Today's stories surprise not only for their content, but also for their form. So let them express new stories and thus help students stand in the mirror in order to get to know themselves and consequently to make the world a better place.

${ }^{6}$ L. Cozolino, The Social Neuroscience of Education. W.W. Norton \& Company Press. New York, London 2013, pp. 21. 


\section{$3^{\text {rd }}$ International Conference On Advanced Research in EDUCATION}

11-14 March, $2021 \quad$ Oxford - United Kingdom

\section{Bibliography}

Bogdańska, A., (2018/2019). Od kreatywności do autopercepcji. Blog i szkolna gazeta internetowa na lekcjach języka polskiego (From creativity to self-perception. Blog and school online magazine on Polish language lessons). Zeszyty Kieleckie. Język Polski w Szkole Ponadpodstawowej, vol. 2, pp. 85-92.

Bogdańska, A., (2012). Rzecz o Szkołach Europejskich (About European Schools), Polonistyka, vol. 3, pp. $44-49$.

Cozolino, L., (2013). The Social Neuroscience of Education. W.W. Norton \& Company Press, U.S.A., U.K: New York, London.

Harari, Y.N., (2018). 21 lekcji na XXI wiek (21 lessons for the 21st Century). Wydawnictwo Literackie Press, Poland: Warsaw.

Izsa K., (2021). Presentation on Culturally Responsive Teaching at the MITA International Teaching Conference organized by the American School in Milan (Italy) on February 6, 2021.

Masłowska D., (2016), Więcej, niż możesz zjeść. Felietony parakulinarne (More than you can eat. Paraculinary feuilletons). Noir sur Blanc Press, Poland: Warsaw. 